\title{
ANALISIS MOTIVASI BELAJAR BERBANTUKAN VIDEO ANIMASI PADA SISWA KELAS V SDN 01 TAMAN
}

\author{
Naniek Kusumawati \\ Dosen, Universitas PGRI Madiun, Jawa Timur, Indonesia \\ naniek@unipma.ac.id
}

\begin{abstract}
Abstrak
Penelitian ini menggunakan penelitian metode kualitatif deskriptif yang terfokus pada analisis motivasi belajar siswa di masa pandemi COVID-19 yang berbantukan video animasi pada pembelajaran tematik di kelas V SDN 01 Taman Kota Madiun, Jawa Timur. Penelitian ini bertujuan untuk mendeskripsikan motivasi belajar siswa di masa pandemi COVID-19 berbantukan video animasi pada pembelajaran tematik. Berdasarkan hasil penelitian bahwa motivasi belajar siswa di masa COVID-19 berbantukan video animasi dikatakan tinggi. Hal ini dibuktikan dengan hasil observasi, wawancara dan angket yang digunakan dalam penelitian yaitu menunjukan bahwasannya siswa memiliki hasrat keinginan belajar yang tinggi, dan merasa senang jika penyampaian materi dilakukan dengan cara Pembelajaran Jarak Jauh (PJJ) disertai menggunakan video animasi. Berdasarkan hasil dari penelitian di SDN 01 Taman Kota Madiun menunjukkan bahwasannya terdapat pengaruh yang signifikan antara media audio visual berbasis video animasi terhadap motivasi belajar siswa. Lebih lanjut penelitian tersebut menjelaskan bahwa penerapan media audio visual berbasis video animasi merupakan salah satu cara efektif yang dapat dilakukan oleh guru atau tenaga pendidik dalam menarik perhatian siswa untuk semangat belajar serta dapat menumbuhkan motivasi dalam diri siswa.
\end{abstract}

Kata Kunci: Motivasi Belajar, Video Animasi, Pembelajaran Tematik.

\section{PENDAHULUAN}

Pendidikan merupakan salah satu kebutuhan yang wajib dimiliki oleh setiap manusia sejak dini. Tanpa pendidikan seseorang tidak akan berhasil dalam menjalani kehidupan di masa sekarang dan yang akan datang. COVID-19 mengakibatkan proses kegiatan belajar mengajar berubah menjadi pembelajaran daring atau online. Siswa dituntut untuk melaksanakan pembelajaran dari rumah. Pandemi COVID-19 motivasi belajar siswa sangat dibutuhkan siswa dalam proses pembelajaran daring. Karena motivasi belajar merupakan faktor dalam menentukan keberhasilan belajar siswa. Siswa akan belajar dengan sungguh-sungguh apabila mempunyai motivasi belajar yang tinggi. Motivasi belajar ada dari beberapa faktor yaitu faktor intrinsik dan ekstrinsik. Faktor intrinsik yaitu keinginan belajar siswa yang timbul dalam diri siswa untu mencapai cita-cita. Kemudian faktor ekstrinsik terjadi di lingkungan belajar dengan kondisi yang kondusif, dengan adanya penghargaan dan kemauan belajar yang menarik keinginan siswa.

Al-Madrasah: Jurnal Ilmiah Pendidikan Madrasah Ibtidaiyah Vol. 6, No. 1, Januari-Maret 2022 
Naniek Kusumawati : Analisis Motivasi Belajar Berbantukan Video Animasi Pada Siswa Kelas V SDN 01 Taman

Menurut Ulifiah (2020)1, mengemukakan bahwa motivasi belajar merupakan salah satu faktor penentu keaktifan dalam proses pembelajaran. Siswa akan belajar dengan sungguh-sungguh apabila mempunyai motivasi belajar yang tinggi. Motivasi merupakan faktor yang mendorong siswa untuk melakukan kegiatan yang akan dicapai. Dalam proses belajar mengajar, kebutuhan berprestasi mengarahkan perbuatan untuk menopang tingkah laku perbuatan yang menjadi landasan utama terhadap proses belajar, dimana hal tersebut sangat menentukan tingkat keberhasilan siswa. Dalam belajar mengajar, motivasi merupakan faktor yang sangat penting, karena dengan adanya motivasi dapat menumbuhkan minat belajar siswa. Bagi siswa yang memiliki motivasi belajar yang tinggi akan melaksanakan kegiatan belajar. Apabila siswa yang mengalami kegagalan dalam belajar, maka hal ini bukanlah semata-mata kesalahan siswa tetapi guru yang belum maksimal dalam memberikan motivasi yang dapat membangkitkan semangat belajar siswa sebab motivation is an essential condition of learning. Hasil dari motivasi belajar akan lebih optimal bila motivasi terus dikembangkan.

Beberapa indikasi dalam mencapai motivasi belajar, meliputi : a) terdapat hasrat dan keinginan belajar; b) dorongan untuk belajar; c) mempunyai harapan dalam diri dan cinta-cita untuk masa depan; d) pembelajaran yang menarik; e) adanya penghargaan ketika belajar; f) lingkungan belajar yang kondusif. Sehingga dengan ini siswa dapat termotivasi untuk mencapai hasil belajar yang lebih baik.

Pembelajaran tematik bertujuan untuk memberikan pembelajaran yang utuh kepada siswa. Pembelajaran tematik juga diartikan pembelajaran yang seiring dengan tumbuh kembangnya siswa dilihat dari diri dan lingkungannya. Namun pada permasalahan dilapangan bahwa pembelajaran tematik bukan pembelajaran yang mudah jika dilakukan secara daring. Kesiapan antara siswa, guru dan orang tua mempengaruhi proses pembelajaran. Masih ada siswa yang kurang bersemangat ketika mengikuti pelajaran di masa COVID-19. Sehingga motivasi belajar siswa menurun dalam melaksanakan pembelajaran

Berdasarkan pemaparan di atas, maka peneliti ingin mengetahui bagaimana motivasi belajar siswa di masa COVID-19 berbantukan video animasi pada pembelajaran tematik di kelas V SD Negeri 01 Taman dengan mengambil judul "Analisis Motivasi Belajar Berbantukan Vidio Animasi Pada Siswa Kelas V SDN 01 Taman”.

\section{METODE PENELITIAN}

${ }^{1}$ Hasanah, Ulfiah. 2020. Analisis Motivasi Belajar Siswa Kelas Vi Terhadap Pembelajaran Tematik. Universitas Pendidikan Indonesia Repository.Upi.Edu Perpustakan Upi.Edu. 
Naniek Kusumawati : Analisis Motivasi Belajar Berbantukan Video Animasi Pada Siswa Kelas V SDN 01 Taman

Jenis penelitian ini adalah penelitian kualitatif deskriptif. Penelitian kualitatif di mana penelitian ini memfokuskan pada mendeskripsikan dan menganalisis hasil dari studi lapangan. Seperti yang diungkapkan oleh Sugiyono $(2014)^{2}$, penelitian kualitatif adalah penelitian yang berasal dari naturalistik yang temuannya tidak melalui perhitungan secara statistik, tetapi dilakukan dengan kondisi yang alamiah. Metode ini biasa digunakan untuk mengungkapkan dan memahami suatu kejadian yang belum diketahui sebelumnya.

Pada penelitian ini, peneliti menggunakan beberapa instrumen dalam pengumpulan data, instrumen penelitian tersebut adalah pedoman observasi, pedoman wawancara, dan angket yang digunakan untuk mengukur motivasi belajar siswa. Objek penelitian ini adalah seluruh siswa kelas V SDN 01 Taman, Kecamatan Taman Kota Madiun Jawa Timur. Selain itu objek penelitian lain adalah guru kelas $\mathrm{V}$.

\section{HASIL DAN PEMBAHASAN}

Berdasarkan hasil penelitian yang dilaksanakan oleh peneliti mengenai Analisis motivasi belajar siswa di masa COVID-19 berbantukan video animasi pada pembelajaran tematik di kelas V SDN 01 Taman, Kecamatan Taman, Kota Madiun menghasilkan beberapa temuan dalam penelitian ini.

Hasrat dan keinginan untuk belajar siswa V SDN 01 Taman Kecamatan Taman Kota Madiun cukup baik. Bahkan siswa memiliki antusias yang tinggi pada pembelajaran hal ini terbukti dari hasil analisis yang dilakukan, bahwa siswa kelas V SDN 01 Taman melaksanakan Pembelajaran Jarak Jauh (PJJ) menggunakan whatsaap group. Diketahui bahwa sebagian besar siswa mempunyai keinginan dan antusiasme untuk terus belajar meskipun pembelajaran dilakukan di luar sekolah. Selain itu siswa juga memiliki semangat untuk aktif belajar. Mungkin masih ada beberapa siswa yang memang belum maksimal dalam melaksanakan kegiatan pembelajaran tematik daring ini. Namun secara keseluruhan pada aspek ini membuktikan bahwa siswa cukup mempunyai hasrat dan keinginan untuk belajar. Motivasi belajar siswa pada intinya dikatakan cukup baik. Hasil tersebut sesuai dengan pendapat Syachtiyani \& Trisnawati $(2021)^{2}$, mengemukakan bahwa motivasi belajar merupakan salah satu faktor penentu keaktifan yang muncul dalam diri siswa untuk mencapai tujuan belajar yang lebih baik dalam proses pembelajaran. Siswa akan belajar dengan semangat dan bersungguh-sungguh apabila mereka mempunyai motivasi belajar yang tinggi.

${ }^{2}$ Syachtiyani, W. R., \& Trisnawati, N. 2021. Analisis Motivasi Belajar Dan Hasil Belajar Siswa Di Masa Pandemi Covid-19. Prima Magistra. Jurnal Ilmiah Kependidikan Vol. 2. No.1 Hal. 90-101.

Al-Madrasah: Jurnal Ilmiah Pendidikan Madrasah Ibtidaiyah Vol. 6, No. 1, Januari-Maret 2022 
Naniek Kusumawati : Analisis Motivasi Belajar Berbantukan Video Animasi Pada Siswa Kelas V SDN 01 Taman

Dorongan dan kebutuhan untuk belajar mencakup banyak hal, diantaranya adalah kebutuhan akan informasi pada siswa tentang materi dan berbagai hal yang menunjang pembelajaran. Semakin tinggi pengetahuan siswa akan semakin tinggi pula peluang untuk keberhasilan belajar siswa. Memang pada dasarnya siswa belum mengetahui tujuan pembelajaran tematik sebenarnya, namun siswa berusaha untuk mencari informasi karena mereka tidak mengetahui informasi terkait dengan tujuan pembelajaran tematik tersebut. Mulai dari membaca bacaan-bacaan tentang pembelajaran tematik maupun bertanya langsung kepada guru. Sehinggga siswa memang memiliiki antusias untuk mencari tahu tujuan pembelajaran tematik tersebut. Hal tersebut memberikan dampak positif pada siswa.

Menurut Nita dkk. (2020) $)^{3}$ mengemukakan bahwa motivasi belajar merupakan kebutuhan yang ada pada setiap siswa untuk melakukan kegiatan agar mencapai tujuan yang diharapkan. Sehingga jiika seseorang memiliki motivasi yang tinggi akan mendapatkan hasil belajar yang memuaskan. Penjelasan ahli tersebut memberikan gambaran bahwa siswa yang memiliki motivasi belajar tinggi akan mendapatkan hasil yang maksimal pada hasil belajarnya. Maka dari itu siswa kelas V SDN 01 Taman Kota Madiun. Dengan antusiasnya menggali informasi-informasi karena merasa itu adalah merupakan kebutuhannya dan salah menjadi satu bukti bahwa siswa tersebut memiliki motivasi yang tinggi untuk menggapai hasil belajar yang baik.

Hal tersebut karena dilandasi adanya harapan dan cita-cita di masa depan pada diri siswa. Aspek ini menjelaskan bahwa setiap siswa perlu memiliki harapan dan cita-cita kedepannya dengan tujuan agar siswa memiliki tujuan hidup dan semangat untuk mengejar citacitanya tak terkecuali cita-citanya dalam hal keberhasilan belajar. Siswa yang memiliki cita-cita dan harapan ke depan tentu akan memiliki motivasi yang tinggi untuk meraihnya. Siswa kelas V SDN 01 Taman Kota Madiun memiliki rasa keingintahuan terhadap materi khususnya pada pembelajaran tematik yang diberikan oleh guru. Oleh karena itu apabila guru hanya memberikan tugas-tugas saja tanpa diberikan materi pembelajaran atau tanpa dijelaskan, tentu akan muncul kebosanan, terbukti pada pernyataan "Saya tidak pernah merasa bosan dengan pembelajaran tematik" mayoritas siswa menjawab tidak setuju. Itu artinya siswa SDN 01 Taman Kota Madiun memiliki antusias dan motivasi yang tinggi untuk meraih harapan dan cita-citanya khususnya dalam hal belajar.

${ }^{3}$ Nita, C. I. R, dkk. 2020. Analisis Motivasi Belajar Siswa IV Pada Pembelajaran Tematik Pada Masa Pandemi Covid-19 Di Sd Negeri 5 Jatiguwi. In Prosiding Seminar Nasional Pgsd Unikama. Vol. 4, No. 1, pp 340-346.

Al-Madrasah: Jurnal Ilmiah Pendidikan Madrasah Ibtidaiyah Vol. 6, No. 1, Januari-Maret 2022 
Naniek Kusumawati : Analisis Motivasi Belajar Berbantukan Video Animasi Pada Siswa Kelas V SDN 01 Taman

Adanya penghargaan dalam belajar sangat penting diberikan kepada siswa yang memang sudah bekerja keras dalam mengikuti proses pembelajaran dan berusaha menjadi yang lebih baik. Siswa merasa senang dan bangga ketika usahanya untuk memberikan jawaban atas pertanyaan baik dari guru maupun dari diskusi diberikan apresiasi atau penghargaan meskipun hanya sekedar acungan jempol atau pujian saja. Hal tersebut dapat meningkatkan motivasi siswa karena merasa dihargai segala usahanya dalam pembelajaran. Terbukti dari pernyataan "Saya senang diacungkan jempol ketika menjawab pertanyaan" mayoritas siswa menjawab setuju bahkan ada yang menjawab sangat setuju. Artinya adanya penghargaan dalam belajar memang sangat penting dan perlu dilakukan baik oleh guru maupun siswa lain agar dapat menambah motivasi siswa dalam belajarnya

Temuan ini sejalan dengan hasil penelitian yang dilakukan oleh Sujantari (2016) ${ }^{4}$, yang menyatakan bahwa penerapan reward dapat mempengaruhi motivasi belajar siswa. Reward secara teoritik berpengaruh terhadap motivasi belajar siswa. Hal tersebut dikarenakan reward mencangkup beberapa aspek yaitu adanya penghargaan dari pendidik (guru), pujian, acungan jempol, senyuman, kata-kata manis, dan hadiah.Oleh karena itu penting bagi guru untuk memberikan reward bagi siswa untuk meningkatkan motivasi belajarnya seperti yang dilakukan oleh guru di SDN 01 Taman Kota Madiun Jawa Timur.

Adanya kegiatan yang menarik dalam belajar ini mencakup model, metode dan media yang digunakan dalam proses pembelajaran khususnya pada pembelajaran daring saat ini. Hal tersebut dirasa sangat perlu karena media yang sesuai akan sangat menentukan antusias belajar siswa. Apabila metode dan media yang digunakan kurang inovatif, tentu siswa akan merasa bosan. Salah satu cara meningkatkan motivasi belajar siswa adalah menerapkan model mengajar yang bervariasi yang digabungkan dengan pemilihan media yang menarik. Model pembelajaran suatu perencanaan atau suatu pola yang digunakan sebagai pedoman dalam merencanakan pembelajaran di kelasatau pembelajaran jarak jauh, sedangkan media yaitu sarana perantara dan tambahan dalam proses pembelajaran. Terbukti pada pernyataan "Saya senang belajar dengan berbantukan video animasi pembelajaran" siswa hampir keseluruhan menjawab sangat setuju dan setuju. Ditambah dengan pernyataan "Saya merasa tertarik dan lebih bersemangat dengan adanya media pembelajaran video animasi" mayoritas siswa juga menjawab setuju. Hal tersebut cukup membuktikan bahwa siswa kelas V SDN 01 Taman Kota Madiun memang cukup antusias apabila pembelajaran menggunakan media yang variatif dan inovatif sehingga tidak membosankan dan hal tersebut bisa berdampak pada motivasi belajar siswa.

${ }^{4}$ Sujantari, N. K., Sujana, I. N., \& Zukhti, A. 2016. Pengaruh Reward Dan Punishment Terhadap Motivasi Belajar Siswa Dalam Pembelajaran IPS (Studi Pada Smp Negeri Q Singaraja Kelas VIII Tahun Ajaran 2015/2016). Jurnal Pendidikan Ekonomi Undiksha. Vol 7. No 2. 
Naniek Kusumawati : Analisis Motivasi Belajar Berbantukan Video Animasi Pada Siswa Kelas V SDN 01 Taman

Temuan tersebut sejalan dengan hasil penelitian Romadhona dkk. (2014)5, yang menunjukkan bahwa terdapat pengaruh yang signifikan antara media audio visual berbasis animasi terhadap motivasi belajar siswa. Lebih lanjut penelitian tersebut menjelaskan bahwa penerapan media audio visual berbasis animasi merupakan salah satu cara efektif yang dapat dilakukan oleh guru dalam menarik perhatian siswa untuk belajar serta dapat menumbuhkan motivasi dalam diri siswa.

\section{KESIMPULAN DAN SARAN}

Berdasarkan hasil penelitian tentang "Analisis Motivasi Belajar Siswa di Masa COVID19 Berbantukan Vidio Animasi pada Pembelajaran Tematik di Kelas V SDN 01 Taman Kota Madiun peneliti telah melakukan kajian pemaparan data, analisa data dan pembahasan maka dapat ditarik kesimpulan sebagai berikut: Pada saat proses Pembelajaran Jarak Jauh (PJJ), siswa selalu berusaha hadir dan mengikuti pembelajaran. Hal ini menunjukan bahwa siswa memiliki hasrat keinginan untuk belajar. Pada saat proses pembelajaran guru menggunakan video animasi untuk menyampaikan materi pembelajaran, dengan ini siswa merasa senang karena dalam penyampaian materi guru tidak hanya menggunakan metode ceramah atau hanya pemberian tugas melalui whatsaap group. Sehingga siswa dapat memahami materi yang disampaikan dengan baik. Mayoritas siswa tidak keberatan jika diberikan pekerjaan rumah. Tetapi disisi lain ada sebagian siswa yang merasa bosan ketika tugas-tugas diberikan secara daring atau melalui whatsaap group tanpa diberikan penjelasan guru.

Guru memberikan apresiasi/pujian lewat kata-kata yang dikirimkan melalui pesan whatsaap group kepada siswa yang aktif bertanya saat proses pembelajaran daring dan membuat siswa menjadi merasa termotivasi ketika usahanya untuk menjawab pertanyaan yang diberikan oleh guru maupun dari diskusi diberikan apresiasi atau penghargaan meskipun hanya sekedar acungan jempol atau pujian saja. Guru menciptakan suasana belajar agar terlihat menarik dan tidak monoton dengan menggunakan media video animasi pembelajaran, hal ini bertujuan untuk menarik perhatian siswa dan mempermudah guru dalam penyampaian materi. Sehingga diharapkan dapat meningkatkan motivasi belajar siswa kelas V SDN 01 Taman Kota MadiunBerdasarkan hasil penelitian yang telah diperoleh, peneliti dapat memberikan saran-saran sebagai berikut: Siswa, siswa diharapkan dapattahu tentang pentingnya pemahaman dan semangat belajar sehingga siswa dapat meningkatkan motivasi belajar dalam dirinya untuk melaksanakan pembelajaran jarak jauh, Sekolah, sekolah diharapkan dapat menerapkan inovasi pembelajaran

${ }^{5}$ Romadhona dkk, .2014. Pengaruh Media Audsi Visual Berbasis Animasi Terhadap Motivasi Belajar Siswa Pada Mata Pelajaran Ekonomi Di Sma Negeri 6 Palembang. Jurnal Profit. Vol 1. No. 1.

Al-Madrasah: Jurnal Ilmiah Pendidikan Madrasah Ibtidaiyah Vol. 6, No. 1, Januari-Maret 2022 
Naniek Kusumawati : Analisis Motivasi Belajar Berbantukan Video Animasi Pada Siswa Kelas V SDN 01

Taman

dengan menyediakan media yang menunjang di sekolah karena sistem dan media pembelajaran tersebut sebagai upaya dan solusi pembelajaran yang efektif khususnya pada masa pandemi COVID-19 untuk meningkatkan motivasi belajar siswa. Guru, diharapkan guru dapat menggunakan media yang inovatif dan variatif, agar siswa tidak merasa bosan dalam mengikuti pembelajaran dan dapat meningkatkan antusias siswa dan motivasi belajarnya.

\section{DAFTAR PUSTAKA}

Nita, C. I. R, dkk. 2020. Analisis Motivasi Belajar Siswa IV Pada Pembelajaran Tematik Pada Masa Pandemi Covid-19 Di Sd Negeri 5 Jatiguwi. In Prosiding Seminar Nasional Pgsd Unikama. Vol. 4, No. 1, pp 340-346.

Romadhona, W., Djahir, Y., \& Barlian, I. 2014. Pengaruh Media Audsi Visual Berbasis Animasi Terhadap Motivasi Belajar Siswa Pada Mata Pelajaran Ekonomi Di Sma Negeri 6 Palembang. Jurnal Profit. Vol 1. No. 1.

Sugiyono. 2014. Memahami Penelitian Kualitatif. Bandung: Alfabeta.

Sujantari, N. K., Sujana, I. N., \& Zukhti, A. 2016. Pengaruh Reward Dan Punishment Terhadap Motivasi Belajar Siswa Dalam Pembelajaran IPS (Studi Pada Smp Negeri Q Singaraja Kelas VIII Tahun Ajaran 2015/2016). Jurnal Pendidikan Ekonomi Undiksha. Vol 7. No 2.

Syachtiyani, W. R., \& Trisnawati, N. 2021. Analisis Motivasi Belajar Dan Hasil Belajar Siswa Di Masa Pandemi Covid-19. Prima Magistra. Jurnal Ilmiah Kependidikan Vol. 2. No.1 Hal. 90-101.

Ulifiah, Hasanah. 2020. Analisis Motivasi Belajar Siswa Kelas Vi Terhadap Pembelajaran Tematik. Universitas Pendidikan Indonesia repository.upi.edu perpustakan upi.edu. 